\title{
Validation and Optimization of an Analytical Method Based on Cold Vapor Atomic Absorption Spectrometry for the Determination of Mercury in Maternal Blood, Cord Blood, and Placenta Samples
}

\author{
Bayram Yüksel $^{a, b, *}$, Seda Kaya ${ }^{\text {b }}$, Dilek Kaya-Akyüzlü ${ }^{\text {b }}$,Zeliha Kayaalt1 ${ }^{\text {, }}$ \\ and Tülin Söylemezoglu ${ }^{\mathrm{b}}$ \\ ${ }^{a}$ Giresun University, Espiye Vocational School, Espiye, 28600, Giresun, Turkey \\ b Ankara University, Institute of Forensic Sciences, Dikimevi, 06590, Ankara, Turkey
}

\section{INTRODUCTION}

Mercury $(\mathrm{Hg})$ is a heavy metal and a highly hazardous environmental pollutant. As a xenobiotic, $\mathrm{Hg}$ remains closely associated with its toxicity to humans. Comparative studies for symptoms of mercury toxicity in humans have been performed (1-3). Human toxicity of mercury varies depending on the chemical structure, the dose and the rate of exposure (2), and can be divided into three classes: elemental mercury, inorganic mercury (i.e., mercuric chloride), and organic mercury (i.e., methyl mercury). Organic mercury is more toxic than inorganic mercury since it can pass through the blood-brain barrier more readily. Hence, exposure to methyl mercury results in serious neuropathological degradations known as Minamata Disease (4). Mercury exerts its genotoxic effects by reacting with the sulfhydryl groups of tubilin and damaging spindle function resulting in chromosal abnormalities and polyploidy (5). In addition, mercury is responsible to produce free radicals leading to DNA damage $(6,7)$.

In humans, exposure to mercury occurs through inhalation of elemental mercury vapor due to the occupational environment, dental amalgam fillings, or ingestion of seafood containing organic mercury compounds $(8,9)$. Mercury has no known physiological functions nor is there a mechanism

\footnotetext{
Corresponding author.

E-mail: bayramyuksel83@gmail.com Tel: +905056283792
}

\section{ABSTRACT}

In this study, a simple and sensitive cold vapor atomic absorption spectrometry (CVAAS) method was developed and validated for the determination of mercury in maternal blood, cord blood, and placenta samples. Biological samples were obtained from 113 mother-newborn pairs. Infant characteristics such as birth weight, birth length, and head circumference were recorded.

Microwave-assisted acid digestion was applied and a cold vapor module was utilized for atomization. The method showed linearity in the range of 0-20 $\mu \mathrm{g} / \mathrm{L}$ with a detection and quantification limit equal to $0.23 \mu \mathrm{g} / \mathrm{L}$ and $0.76 \mu \mathrm{g} / \mathrm{L}$, respectively, as well as very good repeatability not exceeding 3\%. The calibration curve was characterized by a high correlation coefficient $\left(r^{2}=0.9992\right)$. Validation was performed in terms of precision and accuracy with the use of certified reference materials (CRM).

The method was applied to the analysis of spiked CRM samples yielding satisfactory results (97.4-101.2\%). The mean mercury levels of maternal blood, placentas, and cord blood were $3.23 \pm 1.46 \mu \mathrm{g} / \mathrm{L}, 12.24 \pm 11.50$ $\mu \mathrm{g} / \mathrm{kg}, 3.69 \pm 3.44 \mu \mathrm{g} / \mathrm{L}$, respectively. As a result of the statistical analysis, a significant correlation was found between placenta-Hg and cord blood-Hg levels $(\mathrm{r}=+0.231, \mathrm{p}=0.014)$. In addition, birth head circumference and cord blood-Hg levels were found to be correlated to each other $(\mathrm{r}=+0.318, \mathrm{p}=0.033)$. to actively eliminate mercury from the body, resulting in life-long mercury accumulation (10). Like organic mercury compounds, elemental mercury also penetrates the blood-brain and placenta barrier to be trapped as divalent mercury (11).

Analytical detection of mercury in biological samples can be performed with various methods. Traditional flame atomic absorption methods for mercury analysis provide poor sensitivity, since mercury has high volatility with a significant vapor pressure at room temperature. Cold vapor atomic absorption spectrometry (CVAAS), cold vapor atomic fluorescence spectrometry (CVAFS), and inductively coupled plasma mass spectrometry (ICP-MS) have become the leading techniques in recent years $(12,13)$. With ICP-MS instrumentation being one of the most expensive $(14,15)$, CVAAS is more economical and has received great attention with regard to its selectivity and sensitivity.

The main objective of this study was to develop and validate a sensitive method with CVAAS for the determination of mercury in biological samples as a routine toxicological analytic application. The method developed was applied to maternal blood, cord blood, and placenta samples provided from 113 volunteer mother-newborn pairs at the Ankara University, Gynecology Department of Faculty of Medicine. In addition, infant characteristics such as birth weight, birth body length, and head circumference were recorded. Since only limited studies are available con- 
cerning the effect of mercury levels in placenta, maternal blood, and cord blood of newborns, a CVAAS study was developed for this purpose.

\section{EXPERIMENTAL}

\section{Instrumentation}

Mercury levels in maternal blood, cord blood, and placenta samples were measured using a Model Varian AA 240 atomic absorption spectrometer, equipped with a Varian VGA 77 vapor generation system (Varian Corp, Victoria, Australia). Boosted discharge hollow cathode lamps (Agilent, USA) were used for the excitation source for mercury. The digestion procedure for the blood and placenta samples was carried out using a Mars Xpress microwave system (CEM, Matthews, NC, USA) with PTFE microwave digestion vessels. The instrumental operating parameters for the CVAAS system are listed in Table I.

\section{Standard Solutions and Reagents}

Stock solutions of $1000 \mu \mathrm{g} / \mathrm{mL}$ mercury were obtained from SCP Science AA Standards (Canada). Nitric acid $\left(\mathrm{HNO}_{3}, 65 \% \mathrm{v}: \mathrm{v}\right)$, hydrochloric acid ( $\mathrm{HCl}, 37 \% \mathrm{v}: \mathrm{v})$, and sodium hydroxide $(\mathrm{NaOH})$ were purchased from Merck (Darmstadt, Germany). Sodium borohydride $\left(\mathrm{NaBH}_{4}\right)$ was obtained from Fluka (Buchs, Switzerland). All chemicals used for the laboratory process were of analytical reagent grade. Argon gas with a purity of 99.999\% was purchased from a local supplier (Oksan Gaz, Ankara, Turkey). Ultrapure water (Merck Millipore Direct-Q8, Germany) with a resistivity of $18 \mathrm{M} \Omega-\mathrm{cm}$ was used to prepare the solutions for the experimental study. The certified reference materials (CRMs) Seronorm $^{\mathrm{TM}}$ Trace Elements Whole Blood L-2 (Sero AS, Billingstad, Norway) and High Purity Standards
Mercury (Charleston, SC, USA) obtained from a local supplier (SEM AS, Ankara, Turkey) were used for validation of the method.

\section{Sample Collection}

This study involved 113 mothernewborn pairs who have lived in Ankara, Turkey, for at least 5 years. The mothers ranged in age from 19-41 years, with a mean age of $28.8 \pm 5.12$ years. Maternal blood, cord blood, and placenta samples were collected at delivery by cesarean section or spontaneous labor. This study was ethically approved by the Research Ethics Committee of the Medical Faculty, Ankara University (Decision Num-

TABLE I

Operating Parameters for CVAAS System

\begin{tabular}{lr}
\hline Element - & \multicolumn{2}{c}{$\mathrm{Hg}-$} \\
Matrix & Blood, Placenta \\
\hline Instrument & Cold Vapor AAS \\
Concentration Unit & $\mu \mathrm{g} / \mathrm{L} ; \mu \mathrm{g} / \mathrm{kg}$ \\
Instrument Mode & Absorbance \\
Sampling & Auto-Mix \\
Calibration Mode & Concentration \\
Measurement Mode & Integrate \\
Replicates Standard & 3 \\
Replicate Sample & 3 \\
Expansion Factor & 1.0 \\
Wavelength & $253.7 \mathrm{~nm}$ \\
Slit Width & $0.5 \mathrm{R} \mathrm{nm}$ \\
Gain & $64 \%$ \\
Current & $4.0 \mathrm{~mA}$ \\
Background & $\mathrm{BC} \mathrm{OFF}$ \\
Standard 1 & $5.0 \mu \mathrm{g} / \mathrm{L}$ \\
Standard 2 & $10.0 \mu \mathrm{L} / \mathrm{L}$ \\
Standard 3 & $15.0 \mu \mathrm{L} / \mathrm{L}$ \\
Standard 4 & $20.0 \mu \mathrm{g} / \mathrm{L}$ \\
Reslope standard & Standard 2 \\
Total Injection Volume & $15 \mu \mathrm{L}$ \\
Delay Time Before Reading & $45 \mathrm{~s}$ \\
Calibration Algorithm & $\mathrm{Linear}$ \\
Vapor Type & Cold Vapor \\
Recalibration Rate & 50 \\
\hline &
\end{tabular}

ber: 06-243-13/April 8, 2013). Each volunteer was given a written informed consent form in accordance with the principles as established in The Declaration of Helsinki (World Medical Association, Declaration of Helsinki, 1964). The maternal blood and cord blood samples were stored separately at $4^{\circ} \mathrm{C}$ in vacutainer blood collection tubes, and the placenta samples were stored at $-20{ }^{\circ} \mathrm{C}$ until the day of analysis.

\section{Procedure}

To prepare calibration standards at the concentrations of 5.0, 10.0, 15.0 , and $20.0 \mathrm{mg} / \mathrm{L}$, a $1000-\mu \mathrm{g} / \mathrm{mL}$ mercury stock solution was diluted with 30\% (v:v) $\mathrm{HNO}_{3}$. Prior to analysis, 1-mL amounts of blood samples and accurately weighed dry placenta samples (max. $200 \mathrm{mg}$ ) were dissolved in $5 \mathrm{~mL}$ of $65 \%(\mathrm{v} / \mathrm{v})$ nitric acid in Teflon ${ }^{\circledR}$ microwave tubes. Digestion was performed at $1600 \mathrm{~W}$ and $220^{\circ} \mathrm{C}$ for 20 minutes using the Mars Xpress microwave system (CEM, Matthews, NC, USA). Then, the digested solutions were diluted with ultra-pure water to $10 \mathrm{~mL}$ in $15-\mathrm{mL}$ polypropylene tubes. The samples were kept at $4{ }^{\circ} \mathrm{C}$ until the day of analysis. The microwave temperature program is listed in Table II.

\section{Optimization and Sample Pretreatment}

In order to accomplish the best performance from this CVAAS method developed, optimization was based on the selection of the

\section{TABLE II}

Temperature Program For Microwave Digestion

\begin{tabular}{ll}
\hline Max. Power & $1600 \mathrm{~W}$ \\
Power & $100 \%$ \\
Ramp Time & $10 \mathrm{~min}$ \\
Pressure & Maximum \\
Temperature & $210^{\circ} \mathrm{C}$ \\
Hold Time & $10 \mathrm{~min}$ \\
\hline
\end{tabular}


digestion techniques, choice of the appropriate wavelength for the placenta and blood matrix, calibration concentration range in accordance with the mercury concentration in real samples, and establishing the linearity. Preliminary studies were carried out under these subheadings to establish the best methodology for accurate measurements.

Utilizing the Varian AA240 equipped with a Varian VGA 77 vapor generation system, the digested biological samples were oxidized with $10 \%$ (v:v) $\mathrm{HCl}$ solution to alter the different mercury species to their ionic state. Next, mercury was reduced to its elemental state by use of a mixture of $0.3 \%$ $\mathrm{NaBH}_{4}$ (w:v) and $0.5 \% \mathrm{NaOH}$ (w:v). The mercury was then put across a long-pass absorption tube by bubbling a stream of inert gas of argon through the reaction mixture. Finally, the mercury vapor passed through an atomizer cell where the absorbance was measured as a function of mercury concentration at $253.7 \mathrm{~nm}$. The schematic of this process is shown in Figure 1 (16).

The proposed method showed good linearity in the range of $0-20 \mu \mathrm{g} / \mathrm{L}$ and good repeatability not exceeding 3\% for mercury (see Figure 2). The correlation coefficient and equation of the calibration curve were respectively found to be $r^{2}=0.9992$ and Abs $=0.0159 \mathrm{C}+0.0068$, where Abs is the integrated absorbance and $\mathrm{C}$ the mercury concentration in $\mu \mathrm{g} / \mathrm{L}$.

\section{Method Validation}

In order to validate the method in terms of accuracy and precision, certified reference Seronorm ${ }^{\mathrm{TM}}$ Trace Elements Whole Blood L-2 (Sero AS, Billingstad, Norway) was analyzed 10 times in triplicate measurements. The results were compared with the certified values for accuracy, precision, and recovery of the method. Good agreement was obtained between the certified values and the measured $\mathrm{Hg}$ concentrations. The certified mercury content of Seronorm ${ }^{\mathrm{TM}}$ Trace Elements Whole Blood L-2 (Sero AS, Billingstad, Norway) was $15.2 \pm 0.8$ $\mu \mathrm{g} / \mathrm{L}$, while the measured value was
$14.8 \pm 1.1 \mu \mathrm{g} / \mathrm{L}$, with satisfactory recovery and relative standard deviation (RSD) at $97.40 \%$ and $7.43 \%$, respectively. Similarly, the certified mercury content of High Purity Standards Mercury (Charleston, SC, USA) was $100 \pm 0.5 \mu \mathrm{g} / \mathrm{L}$, while measured value was $101.2 \pm 1.4$ $\mu \mathrm{g} / \mathrm{L}$, with the satisfactory percent recovery and relative standard deviation (RSD) at $101.2 \%$ and $1.38 \%$, respectively. A summary of the method validation is given in Table III.

\section{Limit of Detection and Quantification}

The limit of detection (LOD) and lowest limit of quantification (LOQ) were determined based on the standard deviation of the response and the slope of the calibration curve according to ICH guidelines (17) $(\mathrm{LOD}=3.3 \sigma / \mathrm{S}, \mathrm{LOQ}=10 \sigma / \mathrm{S}$, where

TABLE III

Analysis of Certified Reference Materials (CRMs)

\begin{tabular}{lccccc}
\hline \multicolumn{1}{c}{ CRMs } & $\begin{array}{c}\text { No. of Analyses } \\
(\mathrm{n})\end{array}$ & $\begin{array}{c}\text { Certified } \\
\text { Value } \\
(\mu \mathrm{g} / \mathrm{L})\end{array}$ & $\begin{array}{c}\text { Measured } \\
\text { Value } \\
(\mu \mathrm{g} / \mathrm{L})\end{array}$ & $\begin{array}{c}\text { Recovery } \\
(\%)\end{array}$ & $\begin{array}{c}\text { RSD } \\
(\%)\end{array}$ \\
\hline $\begin{array}{l}\text { High Purity } \\
\text { Standards (Hg) }\end{array}$ & 10 & $100 \pm 0.5$ & $101.2 \pm 1.4$ & 101.2 & 1.38 \\
$\begin{array}{l}\text { Seronorm } \\
\text { Trace Elements } \\
\text { Whole Blood L-2 }\end{array}$ & 10 & $15.2 \pm 0.8$ & $14.8 \pm 1.1$ & $97.4 \%$ & $7.43 \%$ \\
\hline
\end{tabular}

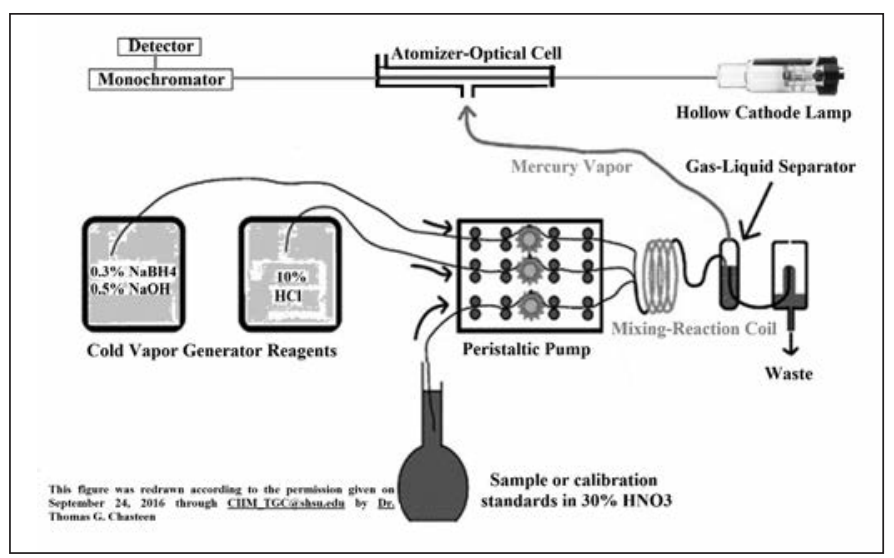

Fig. 1. Schematic diagram of CVAAS. This figure was redrawn by permission given September 24, 2016, through CHM_TGC@sbsu.edu by Dr. Thomas G. Chasteen (16).

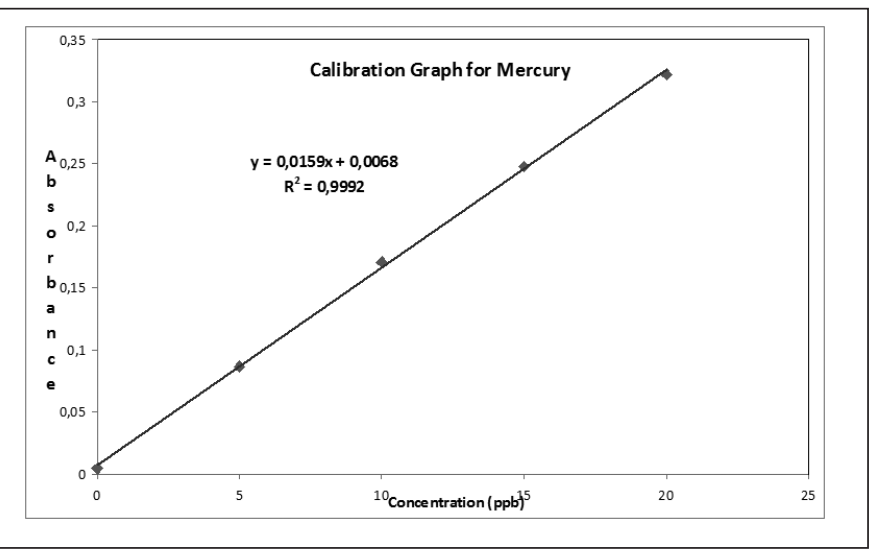

Fig 2. Calibration graph of mercury performed by CVAAS method. 
$\sigma$ is the standard deviation of the response and $\mathrm{S}$ is the slope of the calibration curve). The mercury analysis provided a LOD and LOQ equal to $0.23 \mu \mathrm{g} / \mathrm{L}$ and $0.76 \mu \mathrm{g} / \mathrm{L}$, respectively.

\section{Statistical Analyses}

The findings were statistically assessed based on birth weight, birth length, and birth head circumferences. The Statistical Package for Social Sciences (SPSS) version 16.0 software for Windows ${ }^{\circledR}$ was used for the statistical analysis. All results were expressed as the mean \pm standard deviation (SD) of the mean. Normality of data distribution was evaluated with the KolmogorovSmirnov test, and correlations between the parameters were interpreted using the Pearson's test. The statistical significance was considered as $\mathrm{p}<0.05$. The statistical test results are summarized in Table IV.

\section{RESULTS AND DISCUSSION}

Exposure to mercury is a worldwide public health problem particularly in pregnant women since it is transferred to the fetus via the placenta (18). Maternal hair, maternal blood, and cord blood are the conventional biomarkers for monitoring prenatal exposure to mercury (19). However, the placenta incorporates fetal exposure for almost 36 weeks. Thus, the placenta has become an alternative choice of test sample as it can explain both maternal and fetal exposure to elements (20). On the basis of the points outlined above, the mercury levels in placenta can become an advisable biomarker during pregnancy (21). In this study, the mercury levels in placenta, maternal blood and cord blood samples were measured.

In the present study, infant characteristics such as birth body weight, birth length, and head circumference were recorded in order to investigate whether or not there is any correlations between infant characteristics and mercury levels in the biological samples of placenta, maternal blood, and cord blood. All placentas were collected from the mothers who delivered neonates at

TABLE IV

Statistical Analysis Results of Pearson Correlations

\begin{tabular}{|c|c|c|c|c|c|c|}
\hline & $\begin{array}{c}\text { Birth } \\
\text { Weight }\end{array}$ & $\begin{array}{l}\text { Birth } \\
\text { Length }\end{array}$ & $\begin{array}{l}\text { Head } \\
\text { Circum- } \\
\text { ference }\end{array}$ & $\begin{array}{c}\text { Maternal } \\
\text { Blood } \\
\mathrm{Hg}\end{array}$ & $\begin{array}{c}\text { Cord } \\
\text { Blood } \\
\mathrm{Hg}\end{array}$ & $\begin{array}{c}\text { Placenta } \\
\mathrm{Hg}\end{array}$ \\
\hline Birth Weight & 1.000 & $.692^{* * *}$ & $.681^{* * *}$ & -.112 & -.002 & .027 \\
\hline Sig. (2-tailed) & & .000 & .000 & .239 & .980 & .779 \\
\hline Birth Length & $.692^{* *}$ & 1.000 & $.478^{* * *}$ & -.047 & .077 & .139 \\
\hline Sig. (2-tailed) & .000 & & .001 & .733 & .578 & .312 \\
\hline $\begin{array}{l}\text { Head Circum } \\
\text { ference }\end{array}$ & $.681^{* *}$ & $.478^{* * *}$ & 1.000 & -.083 & $.318^{*}$ & .113 \\
\hline Sig. (2-tailed) & .000 & .001 & & .586 & .033 & .462 \\
\hline $\begin{array}{l}\text { Maternal } \\
\text { Blood Hg }\end{array}$ & -.112 & -.047 & -.083 & 1.000 & -.015 & .000 \\
\hline Sig. (2-tailed) & .239 & .733 & .586 & & .872 & 1.000 \\
\hline Cord Blood Hg r & -.002 & .077 & $.318^{*}$ & -.015 & 1.000 & $.231^{*}$ \\
\hline Sig. (2-tailed) & .980 & .578 & .033 & .872 & & .014 \\
\hline Placenta Hg & .027 & .139 & .113 & .000 & $.231^{*}$ & 1.000 \\
\hline Sig. (2-tailed) & .779 & .312 & .462 & 1.000 & .014 & \\
\hline
\end{tabular}

\footnotetext{
* Correlation is significant at the 0.05 level (2-tailed).
}

** Correlation is significant at the 0.01 level (2-tailed).

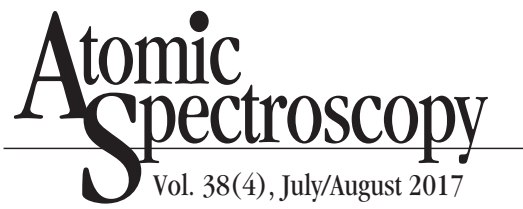

term with normal birth weight (mean $3.32 \pm 0.46 \mathrm{~kg}$ ), birth body length (mean $49.75 \pm 1.97 \mathrm{~cm}$ ), head circumference (mean $35.26 \pm 1.12$ $\mathrm{cm}$ ), and placental weight (mean $632.84 \pm 153.0 \mathrm{~g}$ ). The mercury levels of placenta, maternal blood and cord blood ranged between 3.08 and $87.58 \mu \mathrm{g} / \mathrm{kg}, 0.72$ and 8.05 $\mu \mathrm{g} / \mathrm{L}, 0.15$ and $25.18 \mu \mathrm{g} / \mathrm{L}$, respectively, while the reference dose level suggested by the NRC (2000) was reported as $5.8 \mu \mathrm{g} / \mathrm{L}$ in blood (22). The assessed mercury levels in placenta, maternal blood and cord blood samples are listed in Table V.

\section{CONCLUSION}

Cold vapor atomic absorption spectrometric (CVAAS) analysis of mercury in placenta, maternal blood, and cord blood samples was optimized and validated in this study. The CVAAS method developed for mercury determination in human biological samples, particularly maternal blood, placenta and cord blood, is relatively simple, rapid, and sensitive, offers very good precision expressed as RSD (1.38\%) and recovery (101.2\%) which allows determining mercury at physiological and toxicological concentration levels. In addition, the method proposed is quite competitive in relation to other analytical approaches used for toxicological purposes.

Apart from method validation and optimization for the determination of mercury levels in biological samples, this study also examined whether or not mercury levels in placenta, maternal blood, and cord blood have an effect on newborns. As a result of the statistical analysis; a significant correlation was found between placenta-Hg and cord blood-Hg levels $(r=+0.231$, $\mathrm{p}=0.014)$. In addition, it was found that birth head circumference and cord blood-Hg level were correlated to each other $(\mathrm{r}=+0.318, \mathrm{p}=0.033)$. 
TABLE V

Descriptive Statistics of Mercury Levels in Maternal Blood, Placenta, and Cord Blood Samples

\begin{tabular}{|c|c|c|c|c|c|c|c|}
\hline $\mathrm{N}=113$ & $\begin{array}{c}\text { Maternal } \\
\text { Blood Hg } \\
(\mathrm{ppb})\end{array}$ & $\begin{array}{c}\text { Placenta } \\
\text { Hg } \\
\text { (ppb) }\end{array}$ & $\begin{array}{l}\text { Cord } \\
\text { Blood } \\
\mathrm{Hg} \\
(\mathrm{ppb})\end{array}$ & (year) & $\begin{array}{c}\text { Birth } \\
\text { Length } \\
(\mathrm{cm})\end{array}$ & $\begin{array}{c}\text { Birth } \\
\text { Weight } \\
\text { (g) }\end{array}$ & $\begin{array}{l}\text { Head } \\
\text { Circum- } \\
\text { ference } \\
(\mathrm{cm})\end{array}$ \\
\hline $\begin{array}{l}\text { Mean } \\
\text { Standard }\end{array}$ & 3.31 & 12.3 & 3.62 & 28.80 & 49.75 & 3324.37 & 35.26 \\
\hline Deviation & 1.37 & 11.2 & 3.69 & 5.12 & 1.96 & 461.82 & 1.12 \\
\hline Minimum & 0.72 & 3.08 & 0.15 & 19 & 46 & 2300 & 32.50 \\
\hline Maximum & 8.05 & 87.58 & 25.18 & 41 & 55 & 4500 & 37.50 \\
\hline
\end{tabular}

Consequently, the findings obtained from this study will be a good reference for future studies in mercuryrelated research for biological monitoring during pregnancy.

\section{ACKNOWLEDGMENT}

This study was financially supported by the Ankara University Scientific Research Projects Coordination Unit (BAP). Project Number: 15B0217001.

Received November 4, 2016.

\section{REFERENCES}

1. L.C. Silva-Pereira, P.C. Cardoso, D.S. Leite, M.O. Bahia, W.R. Bastos, M.A. Smith and R.R. Burbano, Braz. J. Med. Biol. Res. 38, 901 (2005).

2. R.A. Bernhoft, J. Environ. Public Health, 460508 (2012). doi: $10.1155 / 2012 / 460508$

3. R. Ynalvez, J. Gutierrez and H. Gonzalez-Cantu, Biometals (in press) (2016). doi:10.1007/s10534016-9967-8

4. C.F. Huang, S.H. Liu, C.J. Hsu and S.Y. Lin-Shiau, Toxicol. Lett. 201, 196 (2011).

5. S. De Flora, C. Benniceli and M. Bagnasco, Mutation Res. 317, 57 (1994).

6. F. Schurz, M. Sabater-Vilar and J. Fink-Gremmels, Mutagenesis 15, 525 (2000).

7. C. Ehrenstein, P. Shu, E.B. Wickenheiser, A.V. Hirner, M. Dolfen, H.
Emons and G. Obe, Chemico-Biological Interactions 141, 259 (2002).

8. World Health Organization (WHO), "Inorganic mercury: environmental health criteria 118 , In "International Programme on Chemical Safety," Geneva, Switzerland (1991).

9. M. Richardson, The Safety of Dental Amalgam, Minister of Health, Canada, ISBN 0-662- 24873-2 (1996).

10. M.C. Houston, J. Clin. Hypertens. 13, 621(2011).

11. J.B. Hursh, M.G. Cherian, T.W. Clarkson, J.J. Vostal and R.V. Mallie, Arch. Environ. Health 31, 302 (1976).

12. D.E. Shrader and W.B. Hobbins, The Determination of Mercury by Cold Vapor Atomic Absorption, Agilent Application Note: AA032, USA [www.agilent.com/chem], (Access Date: October 20, 2016).

13. S.J. Evans, M.S. Johnson and R.T. Leah, Determination of Mercury in Fish Tissue, a Rapid, Automated Technique for Routine Analysis, Agilent Application Note: AA060, USA [www.agilent.com/chem], (Access Date: October 20, 2016).

14. B. Yüksel, Z. Kayaaltı, T. Söylemezoglu, V.A. Türksoy and E. Tutkun, At. Spectrosc. 36(4), 171 (2015).

15. B. Yüksel, Z. Kayaalti, D. KayaAkyüzlü, D. Tekin, and T. Söylemezoglu, At. Spectrosc. 37(3), 114 (2016).

16. T.G. Chasteen, Hydride Generation Atomic Absorption Spectroscopy,
Department of Chemistry, Sam Houston State University, Huntsville, TX 77341, USA. [http://www.shsu.edu/chm_tgc/pr imers/HGAAS.html], (Access Date: October 22, 2016).

17. International Conference on Harmonization (ICH) of Technical Requirements for the Registration of Pharmaceuticals for Human Use, Validation of Analytical Procedures: Methodology (ICBQ2B) (1996).

18. M.R. Karagas, A.L. Choi, E. Oken, M. Horvat, R. Schoeny, E. Kamai, W. Cowell, P. Grandjean and S. Korrick, Environ. Health Persp. 120, 799 (2012)

19. M. Sakamoto, T. Kaneoka, K. Murata, K. Nakai, H. Satoh and H. Akagi, Environ. Res. 103, 106 (2007).

20. G.V. Iyengar and A. Rapp, Sci. Total Environ. 280, 207 (2001).

21. P. Ricketts, N. Basu, H. Fletcher, M. Voutchkov and B. Bassaw, Chemosphere 164, 462 (2016).

22. NRC (National Research Council), Toxicological Effects of Methylmercury, Washington DC, USA, National Academy Press (2000). 